\title{
Insecticide effect of cyantraniliprole on tomato moth Tuta absoluta Meyrick (Lepidoptera: Gelechiidae) larvae in field trials
}

\author{
Patricia Larraín ${ }^{1 *}$, Cristian Escudero ${ }^{2}$, Jorge Morre², and Jeovanny Rodríguez ${ }^{2}$
}

\begin{abstract}
The tomato moth (Tuta absoluta Meyrick, Lepidoptera: Gelechiidae) has traditionally been managed in Chile with organophosphate, pyrethroid, and nereistoxin insecticides; all of these have wide action spectra and high toxicity and many of them have developed rapid resistance. It is therefore important to have new molecules which are effective in controlling this pest; how ever, these molecules must have lower toxicity and greater selectivity for beneficial fauna to produce a more sustainable tomato (Solanum lycopersicum L.) production. The objective was to evaluate the effectiveness of T. absoluta control with cyantraniliprole insecticide, which has desirable characteristics for programs of integrated pest management of tomato; we thus performed three trials in the 2009-2010 and 2010-2011 seasons in the Coquimbo Region, Chile. These trials evaluated the control of T. absoluta using different doses of two formulations: cyantraniliprole 10 OD (oil dispersion) with or without surfactants (Dyne-Amic, Codacide) applied to leaves and cyantraniliprole 20 SC (suspension concentrate) applied to soil. Trials used a randomized complete block design with four replicates. The effect of treatments was compared with standard insecticides and a control without insecticide. The degree of control was estimated by foliar and fruit damage at harvest. Results indicate a reduction in fruit damage between $75 \%$ and $85 \%$ for foliar applications and $82 \%$ for soil applications of cyantraniliprole. It is concluded that both formulations of cyantraniliprole were effective to reduce damage caused by the tomato moth larva in both the foliage and fruit of tomato.
\end{abstract}

Key words: Anthranilic diamides, cyantraniliprole, Solanum lycopersicum, tomato moth.

\section{INTRODUCTION}

The tomato moth Tuta absoluta Meyrick (Lepidoptera: Gelechiidae), originally from South America, is one of the key crop pests in Chile and in many other areas of the world have been invaded by this insect since its entrance in Spain in 2006. This moth causes problems in tomatoes (Solanum lycopersicum L.) grown both in the open and in greenhouses, and if not controlled can produce $50 \%$ to $100 \%$ loss of fruit production (Larraín, 1992; Rodríguez et al., 2006a). The most common management strategy in Chile to control this pest has been insecticides aspersion (Rodríguez et al., 2006b). The most used chemical groups have been organophosphates, carbamates, pyrethroids, and nereistoxins, many of which are highly toxic for mammals and have a wide action spectrum. The appearance of resistance has also been a considerable problem due to the high dependence on chemical control (Salazar and Araya, 1997; 2001; Reyes et al., 2012); thus, future availability of many of the active ingredients is uncertain.

${ }^{1}$ Instituto de Investigaciones Agropecuarias, INIA Intihuasi, Apartado Postal 36/B, La Serena, Chile.

*Corresponding author (plarrain@inia.cl).

${ }^{2}$ Du Pont Chile S.A., Av. El Bosque Norte 500 Of. 1102, Piso 11, Las Condes, Santiago, Chile.

Received: 12 September 2013

Accepted: 30 January 2014.

doi:10.4067/S0718-58392014000200008
It is very important to find new insecticide molecules which are effective in the control of this pest and are less toxic to mammals and beneficial fauna to obtain a more sustainable tomato production. Among emerging insecticides, anthranilic diamides are a new, promising class because of their high efficacy mainly in controlling lepidoptera (Temple et al., 2009); they also have very low toxicity for mammals and favorable eco-toxicological characteristics (Cordova et al., 2006). Mandal (2012) found that a dose of 34-105 $\mathrm{g}$ of the active ingredient cyantraniliprole 10 OD (oil dispersion) did not reduce the population of natural enemies in tomato crops or in the laboratory and that $60-90 \mathrm{~g}$ of this molecule were safe for the lepidopteran egg parasite Trichogramma pretiosum Riley.

These molecules control insects by activating ryanodine receptors in the muscle cells, which induce an uncontrolled liberation of calcium in the muscles of the insect (Lahm et al., 2005), muscular paralysis, and finally death (Cordova et al., 2007).

The objective of this study was to evaluate the efficacy of two formulations of cyantraniliprole to control Tuta absoluta in tomato crops.

\section{MATERIALS AND METHODS}

Three field trials were performed in the 2009-2010 and 2010-2011 seasons in the Pan de Azúcar experimental 
station $\left(29^{\circ} 55^{\prime} \mathrm{S}, 71^{\circ} 14^{\prime} \mathrm{W}\right)$ of the Instituto de Investigaciones Agropecuarias INIA, Coquimbo Region, Chile, to evaluate the effectiveness of the insecticide cyantraniliprole (3-bromo-1-(3-chloro-2-pyridyl)-4'cyano-2'-methyl-6'-(methylcarbamoyl)pyrazole-5carboxanilide; DPX-HGW86, cyantraniliprole, DuPont, Wilmington, Delaware, USA) to control tomato moth $T$. absoluta. The three trials were planted with the tomato var. Patrón, which has an indeterminate growth habit. Trials were carried out in the field on plants conducted on one axis. Each plot consisted of three $4.8 \mathrm{~m}$ rows with 1.5 $\mathrm{m}$ between rows and $0.3 \mathrm{~m}$ between plants. Drip irrigation was used four times per week for $2 \mathrm{~h}$ each time. Weeds were controlled by applying salmon-colored mulch.

In the first season, transplanting occurred on 16 November 2009 and in the 2010-2011 season on 29 November and 3 December 2010 for foliar and soil trials, respectively. Planting dates were chosen to guarantee strong moth pressure. In the two foliar trials we evaluated effectiveness of the experimental product cyantraniliprole 10 OD. Different doses were evaluated with or without Dyne-Amic (methyl esters of C16-C18 fatty acids, polyalkyleneoxide modified polydimethylsiloxane, alkylphenol ethoxylate; Helena Chemical Company, Collierville, Tennessee, USA) and Codacide surfactants (polydimethylsiloxane, polyoxypropylene-polyoxyethylene block copolymer, and methylated vegetable oil; Cheminova Agro, Madrid, Spain); both were compared with the standard insecticide spinosad (mixture of $50 \%$ to $95 \%(2 \mathrm{R}, 3 \mathrm{aS}, 5 \mathrm{aR}, 5 \mathrm{bS}, 9 \mathrm{~S}$, $13 \mathrm{~S}, 14 \mathrm{R}, 16 \mathrm{aS}, 16 \mathrm{bR})$-2-(6-deoxy-2,3,4-tri- $O$-methyl- $\alpha$ L-mannopyranosyloxy)-13-(4-dimethylamino-2,3,4,6tetradeoxy- $\beta$-D-erythropyranosyloxy)-9-ethyl-2,3,3a,5 a ,5b , 6,7,9,10,11,12,13,14,15,16a,16b-hexadecahydro14-methyl-1 $H$-as-indaceno[3,2-d]oxacyclododecine7,15-dione and $50 \%$ to $5 \%(2 \mathrm{~S}, 3 \mathrm{aR}, 5 \mathrm{aS}, 5 \mathrm{bS}, 9 \mathrm{~S}, 13 \mathrm{~S}$, $14 \mathrm{R}, 16 \mathrm{aS}, 16 \mathrm{bS})$-2-(6-deoxy-2,3,4-tri- $O$-methyl- $\alpha$-Lmannopyranosyloxy)-13-(4-dimethylamino-2,3,4,6tetradeoxy- $\beta$-D-erythropyranosyloxy)-9-ethyl-2,3,3a,5 a , 5b ,6,7,9,10,11,12,13,14,15,16a,16b-hexadecahydro4,14-dimethyl- $1 \mathrm{H}$-as-indaceno[3,2-d]oxacyclododecine7,15-dione; Success 40 SC, Dow Agrosciences LLC, Indianapolis, Indiana, USA), thiamethoxam ((EZ)3-(2-chloro-1,3-thiazol-5-ylmethyl)-5-methyl-1,3,5oxadiazinan-4-ylidene(nitro)amine; Actara 25 WG, Syngenta Canada, Ontario, Canada), flubendiamide (3-iodo-N'-(2-mesyl-1,1-dimethylethyl)-N-\{4[1,2,2,2-tetrafluoro-1-(trifluoromethyl)ethyl]-o-tolyl) phthalamide; Fenos 480 SC, Bayer Crop Science AG, Monheim am Rhein, Germany), and an untreated control (Table 1). In the third trial (2010-2011 season), we evaluated the systemic control of T. absoluta with soil application of cyantraniliprole 20 SC (Table 2).

In each of the three trials treatments were arranged in a randomized complete block design with four replicates. Applied treatments and doses are given in Tables 1 and 2. Foliage treatments began $50 \mathrm{~d}$ after transplanting and were applied four times in the first season ( 6 and 21 January and 5

Table 1. Foliar insecticide treatments, doses in trials to control Tuta absoluta in the 2009-2010 and 2010-2011 seasons.

\begin{tabular}{|c|c|c|c|c|}
\hline \multirow[b]{2}{*}{ Treatments } & \multicolumn{2}{|c|}{ 2009-2010 foliar application } & \multicolumn{2}{|c|}{ 2010-2011 foliar application } \\
\hline & Products & Doses Fp ha-1 & Products & Doses Fp ha ${ }^{-1}$ \\
\hline 1 & Cyantraniliprole 10 OD & $500 \mathrm{~mL}$ & Cyantraniliprole 10 OD & $400 \mathrm{~mL}$ \\
\hline 2 & Cyantraniliprole 10 OD & $750 \mathrm{~mL}$ & Cyantraniliprole $10 \mathrm{OD}$ & $500 \mathrm{~mL}$ \\
\hline 3 & Cyantraniliprole 10 OD & $1000 \mathrm{~mL}$ & Cyantraniliprole 10 OD & $600 \mathrm{~mL}$ \\
\hline 4 & Cyantraniliprole 10 OD + Dyne-Amic & $500 \mathrm{~mL}+25 \mathrm{~mL} \mathrm{hL}^{-1}$ & Cyantraniliprole 10 OD & $700 \mathrm{~mL}$ \\
\hline 5 & Cyantraniliprole + Dyne-Amic & $750 \mathrm{~mL}+25 \mathrm{~mL} \mathrm{hL}^{-1}$ & Cyantraniliprole + Codacide & $400 \mathrm{~mL}+250 \mathrm{~mL} \mathrm{hL}^{-1}$ \\
\hline 6 & Cyantraniliprole + Dyne-Amic & $1000 \mathrm{~mL}+25 \mathrm{~mL} \mathrm{hL}^{-1}$ & Cyantraniliprole + Codacide & $500 \mathrm{~mL}+250 \mathrm{~mL} \mathrm{hL}^{-1}$ \\
\hline 7 & Spinosad & $120 \mathrm{~mL}$ & Cyantraniliprole + Codacide & $600 \mathrm{~mL}+250 \mathrm{~mL} \mathrm{hL}^{-1}$ \\
\hline 8 & Thiamethoxam & $200 \mathrm{~g}$ & Cyantraniliprole + Codacide & $700 \mathrm{~mL}+250 \mathrm{~mL} \mathrm{hL}^{-1}$ \\
\hline 9 & Control & - & Spinosad & $120 \mathrm{~mL}$ \\
\hline 10 & - & - & Flubendiamide & $120 \mathrm{~mL}$ \\
\hline 11 & - & - & Control & - \\
\hline
\end{tabular}

Fp: Formulated product.

Table 2. Soil insecticide treatments, doses and application dates and some treatments complemented with foliar sprays to control Tuta absoluta in the 2010-2011 season trial.

\begin{tabular}{|c|c|c|c|}
\hline Treatment & Product & Doses Fp ha ${ }^{-1}$ & Application dates \\
\hline 1 & Cyantraniliprole $20 \mathrm{SC}$ & $500 \mathrm{~mL}$ & 20 January 2011 \\
\hline 2 & Cyantraniliprole $20 \mathrm{SC}$ & $625 \mathrm{~mL}$ & 20 January 2011 \\
\hline 3 & Cyantraniliprole $20 \mathrm{SC}$ & $750 \mathrm{~mL}$ & 20 January 2011 \\
\hline 4 & Cyantraniliprole $20 \mathrm{SC}$ & $875 \mathrm{~mL}$ & 20 January 2011 \\
\hline 5 & Cyantraniliprole $20 \mathrm{SC}$ & $1000 \mathrm{~mL}$ & 20 January 2011 \\
\hline 6 & Cyantraniliprole $20 \mathrm{SC}+$ two foliar sprays of spinosad & $750 \mathrm{~mL}+150 \mathrm{~mL}$ & 20 January 2011; 11 February 2011; 7 March 2011 \\
\hline 7 & $\begin{array}{l}\text { Cyantraniliprole } 20 \mathrm{SC} \text { in soil + foliar spray of } \\
\text { chlorantraniliprole } 20 \mathrm{SC}+\text { indoxacarb } 30 \mathrm{WG}+ \\
\text { chlorantraniliprole } 20 \mathrm{SC}\end{array}$ & $750 \mathrm{~mL}+20 \mathrm{~mL}+200 \mathrm{~g}+20 \mathrm{~mL}$ & 20 January 2011; 11 and 21 February 2011; 7 March 2011 \\
\hline 8 & $\begin{array}{l}\text { Cyantraniliprole } 20 \text { SC in soil + five foliar sprays of } \\
\text { Cyantraniliprole } 10 \text { OD }\end{array}$ & $750 \mathrm{~mL}+550 \mathrm{~mL}$ & $\begin{array}{l}20 \text { January 2011, } 1121 \text { and } 24 \text { February 2011; } 7 \text { and } 22 \\
\text { March } 2011\end{array}$ \\
\hline 9 & Control & - & - \\
\hline
\end{tabular}

Fp: Formulated product. 
and 19 February 2010), but only twice in the second season on 19 January and 22 February 2011. The foliar treatment was applied with a $15-\mathrm{L}$ capacity hand sprayer with water volumes fluctuating between 1500 and $2200 \mathrm{~L} \mathrm{ha}^{-1}$.

There were nine treatments in the soil trial (Table 2): five with doses of cyantraniliprole 20 SC alone 500 , $625,750,875$, and $1000 \mathrm{~mL}$ and three soil applications with doses of $750 \mathrm{~mL}$ cyantraniliprole $20 \mathrm{SC}$ plus foliar applications of spinosad, chlorantraniliprole (3-bromo-4'-chloro-1-(3-chloro-2-pyridyl)-2'-methyl-6' (methylcarbamoyl)pyrazole-5-carboxanilide) Coragen, DuPont de Nemours \& Co., Valdosta, Georgia, USA), indoxacarb (methyl $(S)$ - $N$-[7-chloro-2,3,4a,5-tetrahydro4a-(methoxycarbonyl)indeno[1,2-e] $[1,3,4]$ oxadiazin-2ylcarbonyl]-4-(trifluoromethoxy)carbanilate; Avaunt30 WG, DuPont de Nemours \& Co., Newark, Delaware, USA), cyantraniliprole $10 \mathrm{OD}\left(550 \mathrm{~mL} \mathrm{ha}^{-1}\right)$, and a control. Each plant received a dose calculated for a density of 22000 plants $\mathrm{ha}^{-1}$. Soil applications were performed with a syringe at the base of each plant.

Trial evaluations consisted in counting the number of leaflets damaged by larvae of $T$. absoluta in two plants chosen at random from the central row of each treatment. The leaf trial of the first season was evaluated on 30 December 2009, before the abovementioned application, and on 13, 20, and 27 January, that is, 7, 14, and $21 \mathrm{~d}$ after the first application. In the leaf trial of the second season evaluations were performed on 26 January, 9, and 17 February 2011, that is, 7, 21, and $28 \mathrm{~d}$ after the first application.

Ten plants from the central row of each plot were harvested between 29 January and 17 March 2010 and between 14 and 31 March 2011 in leaf trials and between 9 and 28 March 2011 in the soil trial. At each harvest we evaluated the number of healthy and damaged commercial fruit. With these data we calculated the percentage of fruit damage.

Statistical analysis of results was performed by ANOVA, while mean comparison was performed by Fisher's least significant differences (LSD) test at $\mathrm{p}<$ 0.05with the statistical program SAS 8.0 (SAS Institute, 1999).

\section{RESULTS}

\section{Foliar application trial, 2009-2010}

There were no differences in moth damage among treatments before applications ( $p>0.05)$; the mean number of damaged leaflets in the control was 19 (Table 3). The evolution of damage in the control is indicative of the high pressure of T. absoluta in the 2009-2010 season; this increased 22-fold in less than $1 \mathrm{mo}$ and reached 427 damaged leaflets per plant $21 \mathrm{~d}$ after the application (Table 3). Table 3 also shows that the damage produced by $T$. absoluta larvae 7,14 , and $21 \mathrm{~d}$ after the application was less in all the treatments with cyantraniliprole 10
OD compared with the control and the treatment with thiamethoxam. Fourteen and $21 \mathrm{~d}$ after its application, standard insecticide spinosad showed significantly greater foliar damage $(\mathrm{p}<0.05)$ than in all the treatments with cyantraniliprole10 OD. The insecticide thiamethoxam had no effect on the insect and produced results similar to the control in all the evaluations. Damage was similar among the different doses of cyantraniliprole10 OD tested in all the evaluations. Adding Dyne-Amic surfactant did not produce any significant differences $(\mathrm{p}>0.05)$ compared with the corresponding treatments without surfactant (Table 3 ).

In fruit (Figure 1), the mean damage produced by $T$. absoluta was also significantly less in all the treatments with cyantraniliprole 10 OD compared with the standard spinosad (Success 48 SC), which was less than thiamethoxam and the control. The percentages of damaged fruit were not different $(p>0.05)$ between thiamethoxam and the control $(83 \%$ and $78 \%$ damaged fruit, respectively).

\section{Foliar application trial, 2010-2011}

The results of foliar application in the second season (Table 4) were similar to those of the previous season. The mean damage was similar in all groups before treatment:

Table 3. Mean number of leaflets per plant damaged by Tuta absoluta in foliar treatments in the 2009-2010 season.

\begin{tabular}{lcccc}
\hline Treatments and doses (mL or g ha & -1 \\
\hline Cyantraniliprole 10 OD (500) & $7 \mathrm{DBA}^{1}$ & $7 \mathrm{DAA}^{2}$ & $14 \mathrm{DAA}$ & $21 \mathrm{DAA}$ \\
Cyantraniliprole 10 OD (750) & $16 \mathrm{ab}$ & $46 \mathrm{bc}$ & $119 \mathrm{c}$ & $67 \mathrm{c}$ \\
Cyantraniliprole 10 OD (1000) & $19 \mathrm{ab}$ & $27 \mathrm{c}$ & $103 \mathrm{c}$ & $75 \mathrm{c}$ \\
Cyantraniliprole10 OD (500)+ Dyne-Amic & $10 \mathrm{~b}$ & $34 \mathrm{c}$ & $72 \mathrm{c}$ & $70 \mathrm{c}$ \\
Cyantraniliprole 10 OD (750) + Dyne-Amic & $14 \mathrm{ab}$ & $42 \mathrm{bc}$ & $108 \mathrm{c}$ & $85 \mathrm{c}$ \\
Cyantraniliprole 10 OD (1000) + Dyne-Amic & $27 \mathrm{a}$ & $47 \mathrm{bc}$ & $98 \mathrm{c}$ & $80 \mathrm{c}$ \\
Spinosad (120) & $17 \mathrm{ab}$ & $64 \mathrm{ab}$ & $233 \mathrm{~b}$ & $291 \mathrm{~b}$ \\
Thiamethoxam (200) & $22 \mathrm{ab}$ & $85 \mathrm{a}$ & $341 \mathrm{a}$ & $367 \mathrm{ab}$ \\
Control & $19 \mathrm{ab}$ & $98 \mathrm{a}$ & $401 \mathrm{a}$ & $427 \mathrm{a}$ \\
\hline
\end{tabular}

${ }^{1}$ DBA: Days before application; ${ }^{2}$ DAA: Days after application.

Different letters in the same column indicate significant differences according to the LSD test $(\mathrm{p}<0.05)$.

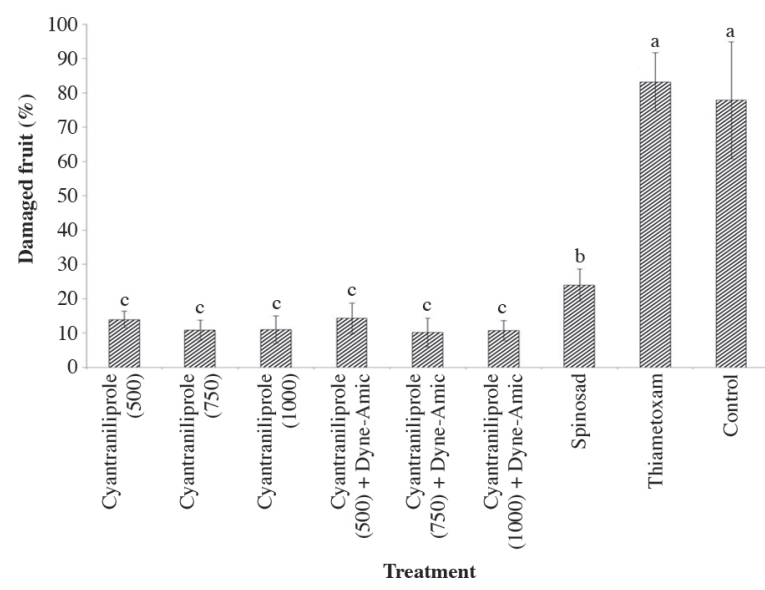

Figure 1. Mean percentages of tomato fruit damaged by Tuta absoluta in the 2009-2010 season. 
there were 11.5 damaged leaflets per plant in the control. Pest pressure in the second season was much less than in the first season; it reached 65.8 damaged leaflets per plant in the control, an increase of only 5.7 times in $40 \mathrm{~d}$.

Table 4 demonstrates that in evaluations 7, 21, and 28 $\mathrm{d}$ after the first application, all treatments significantly reduced $(\mathrm{p}<0.05)$ insect damage compared with the untreated control. As in the first season trial, there were no differences between doses of cyantraniliprole $10 \mathrm{OD}$ (400-700 $\mathrm{mL} \mathrm{ha}^{-1}$ ). Adding the Codacide surfactant did not improve insecticide effectiveness. In contrast with the first season, two standard treatments (spinosad and flubendiamide) in the second season produced a similar decrease in leaf damage, which can be due to lower pest pressure in the second season.

Figure 2 shows that the percentage of damaged fruit was significantly greater in the standard treatment with flubendiamide than in all the treatments with cyantraniliprole $10 \mathrm{OD}$ and standard spinosad. All treatments resulted in significantly less damage to fruit $(\mathrm{p}<0.05)$ than the untreated control.

Table 4. Mean number of leaflets per plant damaged by Tuta absoluta in foliar treatments in the 2010-2011 season.

\begin{tabular}{lrrrr}
\hline Treatments and doses $\left(\mathrm{mL} \mathrm{ha}^{-1}\right)$ & $7 \mathrm{DBA}^{1}$ & $7 \mathrm{DAA}^{2}$ & $21 \mathrm{DAA}$ & $28 \mathrm{DAA}$ \\
\hline Cyantraniliprole 10 OD (400) & $11.6 \mathrm{a}$ & $15.1 \mathrm{~b}$ & $2.8 \mathrm{~b}$ & $23.4 \mathrm{~b}$ \\
Cyantraniliprole 10 OD (500) & $10.3 \mathrm{a}$ & $15.0 \mathrm{~b}$ & $6.2 \mathrm{~b}$ & $21.9 \mathrm{~b}$ \\
Cyantraniliprole 10 OD (600) & $10.5 \mathrm{a}$ & $11.4 \mathrm{~b}$ & $5.3 \mathrm{~b}$ & $23.3 \mathrm{~b}$ \\
Cyantraniliprole 10 OD (700) & $11.6 \mathrm{a}$ & $5.9 \mathrm{~b}$ & $3.3 \mathrm{~b}$ & $19.6 \mathrm{~b}$ \\
Cyantraniliprole 10 OD (400) + Codacide & $9.5 \mathrm{a}$ & $9.1 \mathrm{~b}$ & $4.1 \mathrm{~b}$ & $20.8 \mathrm{~b}$ \\
Cyantraniliprole 10 OD (500) + Codacide & $11.3 \mathrm{a}$ & $17.1 \mathrm{~b}$ & $8.6 \mathrm{~b}$ & $24.3 \mathrm{~b}$ \\
Cyantraniliprole 10 OD (600) + Codacide & $13.4 \mathrm{a}$ & $10.7 \mathrm{~b}$ & $4.9 \mathrm{~b}$ & $25.8 \mathrm{~b}$ \\
Cyantraniliprole 10 OD (700) + Codacide & $12.1 \mathrm{a}$ & $10.1 \mathrm{~b}$ & $3.3 \mathrm{~b}$ & $20.9 \mathrm{~b}$ \\
Flubendiamide (120) & $11.9 \mathrm{a}$ & $11.0 \mathrm{~b}$ & $4.3 \mathrm{~b}$ & $26.0 \mathrm{~b}$ \\
Spinosad (120) & $10.3 \mathrm{a}$ & $10.7 \mathrm{~b}$ & $6.3 \mathrm{~b}$ & $23.8 \mathrm{~b}$ \\
Control & $11.5 \mathrm{a}$ & $38.7 \mathrm{a}$ & $25.5 \mathrm{a}$ & $65.8 \mathrm{a}$
\end{tabular}

${ }^{1}$ DBA: Days before application; ${ }^{2}$ DAA: Days after application.

Different letters in the same column indicate significant differences according to the LSD test $(\mathrm{p}<0.05)$.

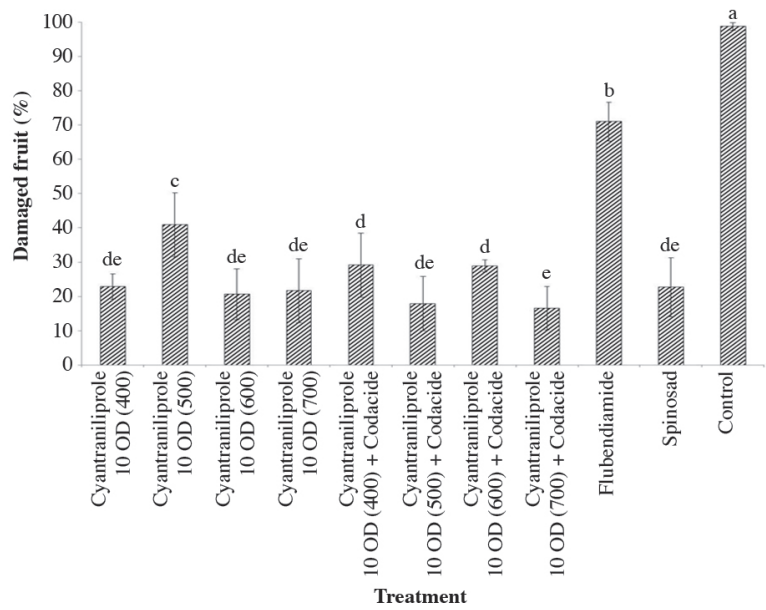

Figure 2. Mean percentages of tomato fruit damaged by Tuta absoluta in the 2010-2011 season.

\section{Soil plus foliar application trial, 2010-2011}

Before the insecticide was applied to the soil all the treatments had similar tomato moth damage; the mean number of damaged leaflets in the control was 7. Foliar damage in the treatments with cyantraniliprole 20 SC applied to the soil and complemented with the foliar treatment is given in Table 5. Only three groups received complementary foliar treatment on 11 February 2011; spinosad in treatment 6 , chlorantraniliprole in treatment 7 , and cyantraniliprole $10 \mathrm{OD}$ in treatment 8 . Since the other foliar applications of these treatments were performed later, we only evaluated their effect on fruit damage. Table 5 shows that soil application with cyantraniliprole 20 SC had a more retarded effect than foliar application since $7 \mathrm{~d}$ after the application almost all the treatments were similar to the control, except in the 625 and $725 \mathrm{~mL} \mathrm{ha}^{-1}$ doses.

Twenty-one days after applying all the cyantraniliprole $20 \mathrm{SC}$ doses applied to the soil, except the lowest $(500 \mathrm{~mL}$ $\left.\mathrm{ha}^{-1}\right)$, showed significantly less leaflet damage than control ( $\mathrm{p}<0.05)$; the highest dose $\left(1000 \mathrm{~mL} \mathrm{ha}^{-1}\right)$ had a mean of 5.8 damaged leaflets compared with 16.7 in the control. The differences between varying doses of cyantraniliprole 20 SC applied to the soil were not significant. Differences in the amount of damage increased considerably $28 \mathrm{~d}$ after the application and reached a mean of 56.1 damaged leaflets in the control, which was significantly greater $(\mathrm{p}<$ $0.05)$ than in the rest of the treatments. In this evaluation, the lowest dose of cyantraniliprole $20 \mathrm{SC}$ applied to the soil $\left(500 \mathrm{~mL} \mathrm{ha}^{-1}\right)$ resulted in greater damage than the 625 and $1000 \mathrm{~mL} \mathrm{ha}^{-1}$ doses and the $750 \mathrm{~mL} \mathrm{ha}^{-1}$ dose complemented with foliar application of spinosad (T6), chlorantraniliprole (T7), and cyantraniliprole 10 OD (T8).

The percentage of damaged fruit was significantly lower $(\mathrm{p}<0.05)$ in all the treatments with cyantraniliprole $20 \mathrm{SC}$ (Figure 3) than in the untreated control where damage reached $88 \%$. No differences in fruit damage were found between doses and between foliar treatments.

Table 5. Mean number of leaflets per plant damaged by Tuta absoluta in several soil treatments in the 2010-2011 season and some treatments with complementary foliar sprayings.

\begin{tabular}{lccc}
\hline Treatments and doses (mL or g ha-1 $)$ & 7DAA & 21DAA & $28 \mathrm{DAA}$ \\
\hline Cyantraniliprole 20 SC (500) & $12.5 \mathrm{ab}$ & $8.6 \mathrm{ab}$ & $11.8 \mathrm{~b}$ \\
Cyantraniliprole 20 SC (625) & $9.4 \mathrm{~b}$ & $5.3 \mathrm{~b}$ & $4.6 \mathrm{c}$ \\
Cyantraniliprole 20 SC (750) & $10.3 \mathrm{~b}$ & $8.0 \mathrm{ab}$ & $6.4 \mathrm{bc}$ \\
Cyantraniliprole 20 SC (875) & $15.2 \mathrm{ab}$ & $6.3 \mathrm{~b}$ & $6.3 \mathrm{bc}$ \\
Cyantraniliprole 20 SC (1000) & $12.0 \mathrm{ab}$ & $5.8 \mathrm{~b}$ & $4.0 \mathrm{c}$ \\
Cyantraniliprole 20 SC (750) + 2 spinosad (150) & $11.5 \mathrm{ab}$ & $6.3 \mathrm{~b}$ & $4.6 \mathrm{c}$ \\
Cyantraniliprole 20 SC (750) + chlorantraniliprole & $12.0 \mathrm{ab}$ & $7.5 \mathrm{~b}$ & $4.2 \mathrm{c}$ \\
20 SC (20) + indoxacarb 30 WG (200)+ & & & \\
chlorantraniliprole 20 SC (20) & & & \\
Cyantraniliprole 20 SC (750)+ & $10.3 \mathrm{~b}$ & $6.5 \mathrm{~b}$ & $3.3 \mathrm{c}$ \\
5 cyantraniliprole 10 OD (550) & & & \\
Control & $24.9 \mathrm{a}$ & $16.7 \mathrm{a}$ & $56.0 \mathrm{a}$ \\
\hline
\end{tabular}

${ }^{1}$ DAA: Days after application.

Different letters in the same column indicate significant differences according to the LSD test $(\mathrm{p}<0.05)$. 


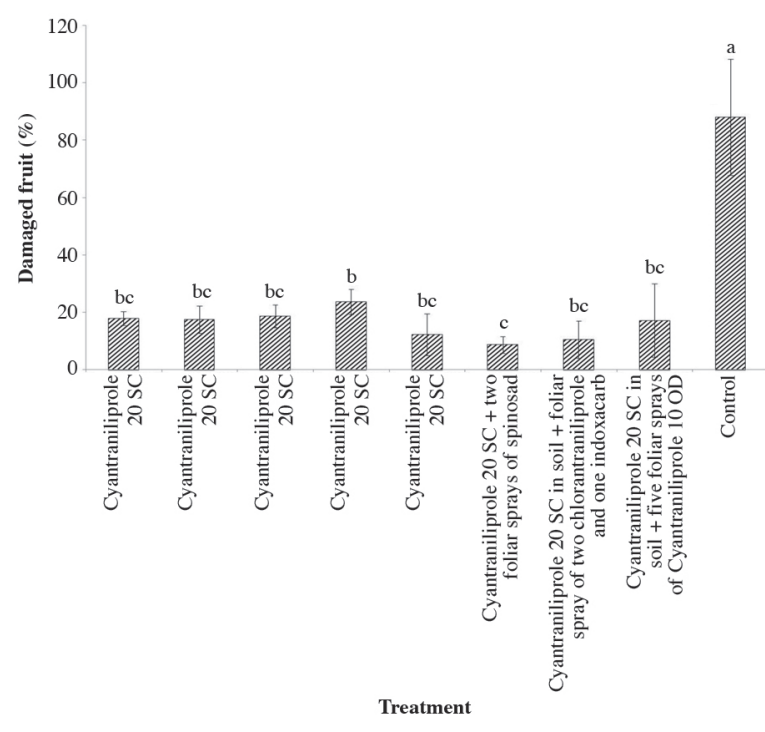

Figure 3. Mean percentages of tomato fruit damaged by Tuta absoluta in soil treatments in the $2010-2011$ season.

\section{DISCUSSION}

Results of the three trials consistently showed the effect of contact and ingestion of anthranilic diamide cyantraniliprole, applied to the foliage or to the soil, on larvae of gelechiid T. absoluta evaluated in tomato leaflets and fruit. These results are concordant with those of Lahm et al. (2005) and Temple et al. (2009), who found very good contact and ingestion activity of a similar anthranilic diamide insecticide on various lepidopteran pests.

The foliar application trials in both seasons showed that doses between $400-1000 \mathrm{~mL} \mathrm{ha}^{-1}$ of cyantraniliprole 10 OD were highly effective in controlling tomato moth and decreasing damage in both foliage and fruit. Similar results were found by Carson et al. (2011), Jacobson and Kennedy (2012), Kuhar et al. (2012), and Mandal (2012) with foliar applications of this insecticide; they found significantly less damage of larvae of corn earworm Helicoverpa zea (Boddie) and other tomato pests. Stansly and Kostyk (2012) found a significant decrease in the number of larvae and damage of the diamondback moth (Plutella xylostella) in a cauliflower crop using foliar applications of cyantraniliprole 10 OD.

Foliar trials also consistently showed that different doses did not vary in effectiveness when compared with the control. Adding Dyne-Amic or Codacide surfactants did not increase product effectiveness. According to these results, we would recommend using the lowest doses of cyantraniliprole $10 \mathrm{OD}$ and to not add surfactant in integrated pest management programs in tomato.

Greater damage observed in the 2009-2010 season, both in foliage and in fruits in the standard spinosad treatment compared with all the doses of cyantraniliprole10 OD in the foliar treatments, can be explained as a decrease in effectiveness of the former due to resident resistant populations of the moth; this was documented by Reyes et al. (2012) in second-stage larvae in field populations of tomato moth in Azapa, Lluta, and Colina (Chile). It is probable that there has also been an overuse of spinosad in the Coquimbo Region to control this pest in recent years.

In the second season, results with spinosad were different and its effectiveness was similar to that of cyantraniliprole 10 OD. This greater effectiveness was probably due to the much lower pest pressure in the second season; there were 25.5 damaged leaflets $21 \mathrm{~d}$ after the first application in this season compared with 401 in 2010 .

The phthalic acid diamide, flubendiamide, was effective in decreasing damage to leaves but not to the fruits where damage was greater than in all the treatments with cyantraniliprole 10 OD. This indicates that with only two foliar applications during the season, flubendiamide residues do not protect the fruit up to harvest.

The product cyantraniliprole 20 SC for soil application showed a good systemic effect; it was transported from the roots to the aerial parts of the plant and effectively controlled larvae and significantly decreased damage caused by the insect to foliage and fruit. The systemic effect of cyantraniliprole $20 \mathrm{SC}$ was also studied by Semtner et al. (2012), who found a significant decrease in the damage of H. zea and Manduca sexta L. to tobacco plants in Virginia when treated via irrigation.

Only one soil application of cyantraniliprole $20 \mathrm{SC}$ in any evaluated dose was sufficient to decrease the percentage of damaged fruit up to $86.4 \%$ compared with the control. Complementary foliar insecticide applications in this trial did not produce less damage in the fruit.

\section{CONCLUSIONS}

Both formulations of cyantraniliprole in all of the evaluated doses were highly effective in reducing damage caused by tomato moth to foliage and fruit and indicate good systemic activity of the product via roots and contact and ingestion via leaves.

Adding Dyne-Amic and Codacide surfactants to the treatments with cyantraniliprole 10 OD did not improve effectiveness of larval control in foliar applications. The standard flubendiamide produced significantly more damage by the moth to the tomato fruit than cyantraniliprole 10 OD.

Under conditions of high pest pressure, cyantraniliprole 10 OD showed better control effectiveness than the standard spinosad. 


\section{LITERATURE CITED}

Carson, W., G. Kund, and J. Trumble. 2011. Effect of insecticides on tomato insects, 2010. Arthropod Management Tests 36:E83.

Cordova, D., E.A. Benner, M.D. Sacher, J.J. Rauh, J.S. Sopa, and G.P. Lahm. 2006. Anthranilic diamides: A new class of insecticides with a novel mode of action, ryanodine receptor activation. Pesticide Biochemistry Physiology 84:196-214.

Cordova, D., E.A. Benner, M.D. Sacher, J.J. Rauh, J.S. Sopa, and G.P. Lahm. 2007. Elucidation of the mode of action of Rynaxypyr ${ }^{\circledR}$, a selective ryanodine receptor activator. p. 121-126. In Ohkawa, H., H. Miyagawa, and P.W. Lee (eds.) Pesticide chemistry, crop protection, public health, and environmental safety. Wiley-VCH Verlag GmbH \& KGaA, Weinheim, Germany.

Jacobson, H., and G. Kennedy. 2012. Residual suppression of tomato fruitworm damage to fresh market tomato by early season application of Cyazypyr. Arthropod Management Tests 37:E71.

Kuhar, T., H. Doughty, A. Wilmer, and J. Jenrette. 2012. Evaluation of foliar insecticides for the control of foliar insects in spring tomatoes in Virginia. Arthropod Management Tests 37:E73.

Lahm, G.P., T.P. Selby, J.H. Freudenberger, T.M. Stevenson, B.J. Myers, G. Seburyamo, et al. 2005. Insecticidal anthranilic diamides: A new class of potent ryanodine receptor activators. Bioorganic \& Medicinal Chemistry Letters 15:4898-4906.

Larraín, P. 1992. Plagas en cultivos bajo plástico. Investigación y Progreso Agropecuario La Platina (Chile) 73:41-52.

Mandal, S.K. 2012. Bio-efficacy of Cyazypyr 10\% OD, a new anthranilic diamide insecticide, against the insect pests of tomato and its impact on natural enemies and crop health. Acta Phytopathologica et Entomologica Hungarica 47:233-249.
Reyes, M., K. Rocha, L. Alarcón, M. Siegwart, and B. Sauphanor. 2012. Metabolic mechanisms involved in the resistance of field populations of Tuta absoluta (Meyrick) (Lepidoptera: Gelechiidae) to spinosad. Pesticide Biochemistry and Physiology 102:45-50.

Rodríguez, M., M. Gerding, y A. France. 2006a. Efectividad de aislamientos de hongos entomopatógenos sobre larvas de polilla del tomate, Tuta absoluta Meyrick (Lepidoptera: Gelechiidae). Agricultura Técnica (Chile) 66:159-165.

Rodríguez, M., M. Gerding, y A. France. 2006b. Selección de aislamientos de hongos entomopatógenos para el control de huevos de la polilla del tomate, Tuta absoluta Meyrick (Lepidoptera: Gelechiidae). Agricultura Técnica (Chile) 66:151-158.

Salazar, E., y J.E. Araya. 1997. Detección de resistencia a insecticidas en la polilla del tomate. Simiente 67:8-22.

Salazar, E., y J.E. Araya. 2001. Respuesta de la polilla del tomate, Tuta absoluta (Meyrick), a insecticidas en Arica. Agricultura Técnica (Chile) 61:151-158.

SAS Institute. 1999. SAS Online Doc, Version 8. SAS Institute, Cary, North Carolina, USA.

Semtner, P., D. Reed, and J. Jones. 2012. Systemic insecticides applied by various methods for insect control on Flue-cured tobacco in Virginia. Arthropod Management Tests 37:F93.

Stansly, P., and C. Kostyk. 2012. Control of diamondback moth on cauliflower. Arthropod Management Tests 37:E21.

Temple, J.H., P.L. Pommireddy, D.R. Cook, P. Marcon, and B.R. Leonard. 2009. Susceptibility of selected lepidopteran pests to Rynaxypyr®, a novel insecticide. Journal of Cotton Science 13:23-31. 